\title{
Counselor's Knowledge, Attitude and Practice of Infant and Young Child Feeding (IYCF) Counselling
}

\author{
Syifa F. Syihab ${ }^{1}$, Ayu Mutiara Santanu ${ }^{1}$, Delita Septia Rosdiana ${ }^{1}$, Isti Kumalasari ${ }^{1 *}$
}

ABSTRACT

Background: It needs an effort to reduce the prevalence of undernutrition with the proper IYCF practices. IYCF promotion and counseling activities for caregivers can increase the success of IYCF implementation and reduce the prevalence of malnutrition.

Objectives: The objective of this study was to determine the association between the level of education, knowledge, and attitude of Posyandu counselors on IYCF practice in the Parongpong District of West Bandung Regency.

Materials and Methods: This research used a cross-sectional study with a consecutive sampling technique. The data collection was conducted from June until August 2020, involving 67 respondents. The dependent variable was Posyandu counselor practice; meanwhile, the independent variables were knowledge and attitude. Descriptive analysis was conducted to describe the characteristics of the respondents, and the multivariate test used multiple logistic regression. Results: Bivariate analysis showed that only level of education had a significant association with a p-value of 0.024. Further analysis using a multivariate test showed that the variables that significantly related to the practice of IYCF counseling were the level of education, knowledge, and attitude, which were controlled by the confounding variable for the period of being a counselor.

Conclusion: The level of education, knowledge, and attitude of Posyandu counselors in IYCF counseling practice was an essential factor that can improve children's nutritional status.

Keywords: IYCF; knowledge; Posyandu counselor

\section{BACKGROUND}

Nutritional problems result from internal factors with cultural and socio-economic conditions in the community. The term Double Burden of Malnutrition (DBM) is the coexistence of overnutrition (overweight and obesity) alongside undernutrition (stunting and wasting) at all levels of the population, where many of these events are found in poor and middle-income countries (low-income and middle-income countries / LMICs). A study in 2019 showed that Indonesia is a country with the most considerable incidence of DBM in the world ${ }^{1}$. Nutritional problems can occur in every stage of the life cycle, starting from babies, infants, children, adults, and the elderly. However, the most critical periods of human life are the periods of intense growth and development stages (the first 1000 days of a child's life) ${ }^{2}$. Stunting in the childhood period is one of the significant factors that hinder human development, and globally affects around 162 million children under the age of $5^{3}$. A child is classified as stunting if the length or height according to their age is lower than the applicable standards ${ }^{4}$. The prevalence of stunting in Indonesia is the fifth largest in the world. Indonesia Basic Health Research Data (Riskesdas) in 2018 showed the prevalence of stunting (body height/ age) was $30.8 \%$, whereas the number of short toddlers was $19.3 \%$, and very short toddlers were $11.5 \%$. West Java is one of the provinces with a stunting rate of $31.1 \%$, and in West Bandung Regency, the number has reached $13.23 \%{ }^{5}$.

The lack of nutritional intake commonly causes growth failure conditions in children under five for a long time and recurrent infections. In contrast, these two factors are influenced by inadequate knowledge, especially in the first 1000 days of a child's life ${ }^{6}$. The 1000 days period is a critical factor in stunting children under five years and has a long-term effect ${ }^{7}$. Stunting in children, especially in children under two years of age, causes long-term effects such as lower body height as an adult, economic level/income, school achievement, and the risk of developing chronic disease as an adult 8 .

Nutritional problems can affect all aspects of life, especially the economic aspect and individual health status in the future. Efforts to reduce the prevalence of malnutrition can be made with adequate

\footnotetext{
${ }^{\mathbf{1}}$ Faculty of Health and Sports Education, Universitas Pendidikan Indonesia Jl. Dr. Setiabudhi No. 229, Bandung, Jawa Barat 40154, Indonesia.

*Correspondence : E-mail: ikumalasari@upi.edu Phone +6281575722910

Copyright (C) 2021; Jurnal Gizi Indonesia (The Indonesian Journal of Nutrition), Volume 10 (1), 2021 e-ISSN : 2338-3119, p-ISSN: 1858-4942
} 
and proper Infant and Young Child Feeding (IYCF). The practice of IYCF starts with the early initiation of breastfeeding, followed by giving exclusive breast milk and providing appropriate complementary feeding 9. However, the lack of knowledge and practical skills to provide adequate additional feeding for infants and children can affect the nutritional status of children and contribute to the high prevalence of stunting ${ }^{10} 11$. IYCF promotion and counseling for caregivers are known to increase the success of IYCF implementation and reduce the number of malnutrition cases ${ }^{12}$. Implementing IYCF counseling is also known to have an indirect effect on improving children's nutritional status, such as reducing the incidence of malnutrition and stunting in children ${ }^{13}$.

The delivery of information about IYCF practice by health workers or counselors is often considered ineffective and inadequate so that caregivers do not acquire adequate knowledge ${ }^{14}$. Various indicators such as lack of information regarding IYCF techniques/practices and lack of nutrition counseling materials for children who are not breastfed are known to affect the success of the IYCF program ${ }^{10}$. Good IYCF promotion and counseling can help caregivers make the right decision to provide nutritious food for their children. Posyandu in Indonesia is an integrated health service post that provides primary health service, especially for children and pregnant women. Adequate knowledge of Posyandu counselors in the IYCF counseling practice is an essential factor that can improve children's nutritional status. Currently, there is not much research in Indonesia that study the level of IYCF knowledge, attitudes, and practices of Posyandu counselor. A study in India shows that parents will implement better IYCF practices when counseling from counselors who have higher knowledge ${ }^{15}$. This study aims to determine the association between the level of education, knowledge, and attitude of Posyandu counselors on IYCF practice in the Parongpong District of West Bandung Regency.

\section{MATERIALS AND METHODS}

This study used a cross-sectional design with a consecutive sampling technique. All counselors are invited, and those present are taken as study samples. There are 67 Posyandu counselors involved in this study from 56 Posyandu in three villages in Parongpong District. Data for the Posyandu counselors were obtained through the Nutrition Driving Team (Tim Penggerak Gizi) from the Parongpong Community Health Center. The inclusion criteria in this study are the Posyandu counselor who can communicate in the Indonesian language and can read well; meanwhile, the exclusion criteria are the counselor absent during the data collection process and did not fill all the questions in the questionnaire. First, descriptive analysis was conducted to describe the characteristics of the respondents. In the next stage, the chi-square bivariable test was used to determine the relationship between two categoric variables, where significant variables showed a significance value of $\mathrm{p}<0.05$. Furthermore, a multivariate test is carried out to determine which variables meet the logistic regression equation model. Logistic regression is a method of predictive analysis carried out when the dependent variable in testing is binary. This study has been approved by the Medical and Health Research Ethics Committee (MHREC) Faculty of Medicine, Public Health, and Nursing Universitas Gadjah Mada, $\mathrm{KE} / \mathrm{FK} / 0994 / \mathrm{EC} / 2020$.

\section{RESULTS}

\section{Respondent Characteristic}

The research was conducted in the Parongpong District of West Bandung Regency. A total of 67 Posyandu counselors participated in this study. A descriptive analysis of the respondents is presented in

The average age of Posyandu counselors was 43.18 years old, with the oldest being 63 years old. Most of them were graduated from high school (47.8\%) and worked as housewives (97\%). Posyandu counselors have an average monthly income of IDR 2,046,296.3, with the lowest income of IDR 600,000. On average, the counselors had worked for 7.8 years, and the counselors who had worked the longest were 34 years. Most Posyandu counselors have not received IYCF training $(73.1 \%)$. The measurement results based on the questionnaire showed that the counselor's average score for knowledge was 76.2, the average attitude score was 46.25 , and the average practice score was 68.8 .

\section{Bivariate Test}

A bivariable test was conducted on the IYCF counseling practice and other variables in this study. Table 2 summarizes the result of the bivariable test. Knowledge, attitude, and IYCF practice were divided into two categories with a cut-off point from the median score. The results showed that only the education variable had a significant relationship with IYCF counseling practice, with a value of $0.024, p$ $<0.05$.

The results of data analysis in Table 2 show that almost all variables did not meet the 
requirements for multivariate analysis, except for the education and attitude variables which have a p-value less than 0.25. However, since the other variables are also considered essential variables, the researcher decided to include all the variables for the multivariate logistic regression test.
The next step is carried out by conducting an interaction test and a confounding test. The results show that there is no interaction between the variables.

Tabel 1. Respondent Characteristic

\begin{tabular}{|c|c|c|c|c|}
\hline Variable & Mean & SD & Min & Max \\
\hline Age & 43.18 year & 9.2 year & 25 year & 63 year \\
\hline \multicolumn{5}{|l|}{ Education (n, \%) } \\
\hline Primary School & $18(26,9 \%)$ & & & \\
\hline Junior High School & $7(10.4 \%)$ & & & \\
\hline Senior High School & $32(47.8 \%)$ & & & \\
\hline College & $10(14.9 \%)$ & & & \\
\hline \multicolumn{5}{|l|}{ Occupation (n, \%) } \\
\hline Housewife & $65(97 \%)$ & & & \\
\hline Entrepreneur & $1(1.5 \%)$ & & & \\
\hline Lecturer & $1(1.5 \%)$ & & & \\
\hline Monthly income $(n=54)$ & IDR 2,046,296.3 & IDR $1,427,157.5$ & IDR 600,000 & IDR $8,000,000$ \\
\hline Service period & 7.9 year & 7.8 year & 1 year & 34 year \\
\hline \multicolumn{5}{|l|}{ IYCF Training $(\mathrm{n}, \%)$} \\
\hline No & $49(73.1 \%)$ & & & \\
\hline Yes & $18(26.9 \%)$ & & & \\
\hline Knowledge & 76.2 & 0.76 & 30 & 100 \\
\hline Attitude & 46.25 & 0.79 & 1 & 7 \\
\hline Practice & 68.8 & 17.38 & 8 & 76 \\
\hline
\end{tabular}

Table 2. Bivariable Test of IYCF Counseling Practice

\begin{tabular}{lcccc}
\hline Variable & \multicolumn{2}{c}{ IYCF Counseling Practice } & total & \multirow{2}{*}{ p-value } \\
\cline { 2 - 3 } & Poor & Good & & \\
\cline { 1 - 3 } Age & 43.18 & 9.2 & 43.18 & 0.784 \\
Education (n, \%) & & & & 0.024 \\
$\quad$ Primary School & $4(22.2)$ & $14(77.8)$ & $18(26,9 \%)$ & \\
$\quad$ Junior High School & $2(28.6)$ & $5(71.4)$ & $7(10.4 \%)$ & \\
$\quad$ Senior High School & $19(59.4)$ & $13(40.6)$ & $32(47.8 \%)$ & \\
$\quad$ College & $7(70)$ & $3(30)$ & $10(14.9 \%)$ & \multirow{2}{*}{0.366} \\
Occupation (n, \%) & & & & \\
$\quad$ Housewife & $31(47.7)$ & $34(52.3)$ & $65(97 \%)$ & \\
$\quad$ Entrepreneur & $1(100)$ & 0 & $1(1.5 \%)$ & \\
$\quad$ Lecturer & 0 & $1(100)$ & $1(1.5 \%)$ & \\
Service period & 7.9 & 7.8 & & \\
$\quad$ < 1 year & $3(33.3)$ & $6(66.7)$ & $9(13.4 \%)$ & \\
$\quad$ 1-10 year & $23(53.5)$ & $20(46.5)$ & $43(64.2 \%)$ & \\
$\quad$ > 10 year & $6(40)$ & $9(52.2)$ & $15(22.4 \%)$ & \\
IYCF training (n, \%) & & & & \\
$\quad$ No & $25(51)$ & $24(49)$ & $49(73.1 \%)$ & \\
$\quad$ Yes & $7(38.9)$ & $11(61.1)$ & $18(26.9 \%)$ & \\
Knowledge (n, \%) & & & & 0.378 \\
$\quad$ Poor & $18(52.9)$ & $16(47.1)$ & $34(50.7 \%)$ & \\
$\quad$ Good & $14(42.4)$ & $19(57.6)$ & $33(49.3 \%)$ & \\
Attitude (n, \%) & & & & \\
$\quad$ Poor & $13(59.1)$ & $9(40.9)$ & $22(32.8 \%)$ & \\
$\quad$ Good & $19(42.2)$ & $26(57.8)$ & $45(67.2 \%)$ & \\
\hline
\end{tabular}

Copyright (C) 2021; Jurnal Gizi Indonesia (The Indonesian Journal of Nutrition), Volume 10 (1), 2021 e-ISSN : 2338-3119, p-ISSN: 1858-4942 


\section{Logistic Regression Model}

The results of the multivariate logistic regression test are presented in Table 3 . The results of the multivariate analysis showed that the education level, knowledge, and attitude had a significant relationship with the practice of IYCF counseling, controlled by the service period.

Table 3. Fix Model from Multivariate Logistic Regression Test

\begin{tabular}{lccccc}
\hline Variable & \multirow{2}{*}{$\mathrm{B}$} & \multirow{2}{*}{ P-value } & \multirow{2}{*}{ OR } & \multicolumn{2}{c}{ 95\% CI } \\
& & 0.022 & & & \\
\hline Education & & & & \\
$\quad$ Junior High School & -1.386 & 0.095 & 0.25 & 0.049 & 1.275 \\
$\quad$ Senior High School & -3.824 & 0.002 & 0.02 & 0.002 & 0.244 \\
$\quad$ College & -21.483 & 0.999 & 0.00 & 0.000 &. \\
Service period & & 0.170 & & & \\
$\quad$ 1-10 year & -2.161 & 0.077 & 0.1 & 0.010 & 1.268 \\
$\quad>10$ year & -1.413 & 0.301 & 0.2 & 0.017 & 3.541 \\
Knowledge & 1.744 & 0.027 & 5.7 & 1.216 & 26.924 \\
Attitude & 2.140 & 0.010 & 8.4 & 1.666 & 43.356 \\
\hline
\end{tabular}

Based on the analysis, the most dominant variable was attitude. This result also showed that the attitude variable's Odds Ratio (OR) value was 8.5. This result indicated that Posyandu counselors with poor variables are most likely to give poor IYCF counseling practices 8.5 times greater than Posyandu counselors with a good attitude toward IYCF counseling practice. The other result was that the Odds Ratio (OR) value of the knowledge variable was 5.7. This result shows that Posyandu counselors with a lack of IYCF knowledge have a 5.7 times greater possibility to conduct poor IYCF counseling practice.

\section{DISCUSSION}

The Convention on the Child's Rights states that every child has the right to receive good nutrition. Providing optimal infant and child feeding (IYCF) in the first 1000 days of life can prevent the mortality rate for children under five years by up to $20 \%{ }^{16}$. About $60 \%$ of death in children under five years old are directly or indirectly related to malnutrition ${ }^{17}$. Malnutrition cases in children can be caused by parents' lack of understanding about providing nutritious food for children ${ }^{18}$. A study in 2012 revealed that the lack of knowledge and practical ability to provide supplementary feeding for infants and children could affect the nutritional status of children and further contribute to the highly increasing number of stunting in the world 19 . Community health workers (CHWs) are wellestablished as change agents for promoting health attitude change among community members. However, their knowledge and counseling skills play an essential role in promoting optimal infant and young child feeding practices (IYCF) ${ }^{16}$. Counseling ability is a skill that must be possessed by a counselor in translating knowledge of IYCF into messages or interpreting existing IYCF practices to provide suggestions or advice for the caregiver ${ }^{20}$.

The average age of Posyandu counselors is 43 years, which can be categorized as an adult person ${ }^{21}$. Adults have a greater responsibility because they deal with a broad group of people. Counselors' experience and age are related to their ability to provide information and understanding related to IYCF for mothers in their environment. Research by Faridi et al. (2020) states a correlation between the counselor's age and the implementation of the IYCF in Pandeglang, Banten. Senior counselors and counselors who are over 35 years old tend to be more active in assisting mothers in implementing PMBA compared to younger counselors ${ }^{22}$.

Posyandu counselors' knowledge showed an average score of 76.2 , so it can be concluded that most of the Posyandu counselors have poor knowledge of IYCF, especially about infant feeding and basic knowledge of breastfeeding. According to Kohli and Chahda (2017), if the score for the subject's knowledge of IYCF is more than 80 , the subject is considered to have a good level of IYCF knowledge ${ }^{16}$. Posyandu counselors are health promotion agents and positively impact health practices in the community ${ }^{23}$. The practice of IYCF for the caregiver in the community, including the practice of breastfeeding, introduction to complementary feeding, the suitability of the amount, 
frequency, and variety of foods, is influenced by the knowledge, abilities, attitude, and motivation of health counselors played an essential role in conveying IYCF messages to caregiver 14162425 . In practice, the success of IYCF for children under five is inseparable from the ways the counselors explain the appropriate IYCF practice and grid. Contento (2011) explains that the success of external factors such as the availability of food and the role of counselors is one of the environmental factors that affect the practice of IYCF from caregiver to the children. The ability of counselors to build communication is highly dependent on empathy, the ability to listen, and pay attention to the child's feeding history ${ }^{26}$.

In addition to knowledge, we also measured the attitude and practices aspect of Posyandu counselors regarding breastfeeding and complementary feeding. The analysis results showed that $52.9 \%$ of Posyandu counselors had poor knowledge of IYCF counseling practice, and $59.1 \%$ had a poor attitude toward IYCF counseling practice. Attitude parameters in this study were collected through agreeing and disagreeing statements regarding the practice of IYCF based on the counselors' opinions of the material or concepts of IYCF practice. This value becomes a benchmark that the counselors' low attitudes regarding IYCF were affected by the lack of knowledge from the counselors (Table 1). Therefore, counselors' attitude data is obtained from practice when giving IYCF counseling to caregivers. In addition to the knowledge aspect, the results of this study also show that the attitude aspect shows a low score. This is presumably because the practice of IYCF counseling for mothers in the community has not been carried out routinely and focuses on measuring children's nutritional status without giving a proper IYCF education to children's caregivers.

The IYCF program has been proven to reduce the number of morbidity and mortality. Health workers have a significant role in providing education and support for caregivers regarding breastfeeding and infant feeding ${ }^{27}$. The results of the descriptive analysis showed that most Posyandu counselors only graduated from high school and worked as housewives. Posyandu counselors in Indonesia are not health workers who can provide health counseling practice. They are generally individuals who have received training and knowledge from the Community Health Center (Puskesmas). Therefore, the level of knowledge, practice, and attitude of Posyandu counselors is minimal. World Health Organization (WHO) and the Indonesian Ministry of Health has various guidelines covering the implementation of IYCF counseling activities 52829 . However, not all Posyandu counselors have access to received adequate IYCF training. In this research, we found that most Posyandu counselors have not received IYCF training $(73.1 \%)$. IYCF training is a critical factor that ensures the community's successful implementation of IYCF practices. IYCF training makes Posyandu counselors manage to provide appropriate counseling to the community and help the caregivers provide nutritious and good food for babies and children ${ }^{30}$.

The multivariate analysis in this study indicates that the level of education, knowledge, and attitude has a significant relationship with the practice of IYCF counseling. We find evidence for an association between health worker compliance and client health attitudes; however, small effect sizes suggest that attitude change is multifactorial and affects factors beyond care quality. Improvements to the technical quality of care may contribute to desired health outcomes. Health worker compliance may impact caregiver attitude through pathways other than the mediating pathway of IYCF knowledge. Health worker counseling compliance was significantly and positively associated with health worker knowledge. IYCF practiced at the age of 6-24 months must be done correctly and appropriately. Feeding errors during this period can lead to malnutrition and stunting. The role of counselors is needed to prevent the chain of nutritional problems that occur in society. According to Notoatmojo (2007) in Wahyuningsih and Handayani (2015), educational factors can influence a person's knowledge, which states that a person's education will make it easier to process information. However, the statistical analysis results show that the level of education does not affect one's knowledge, as well as with service period, so it requires further analysis or study whether it has nothing to do with or is there other factors that influence it ${ }^{31}$. The IYCF training is a crucial factor in the implementation of counseling. Even though a counselor has a high level of education, if they have never received IYCF training, their ability to carry out IYCF counseling becomes very limited ${ }^{32}$.

Based on table 3, the result showed that Posyandu counselors with a lack of IYCF knowledge have a 5.7 times greater possibility to conduct poor IYCF counseling practice. Other results showed that the attitude variable's Odds Ratio (OR) value was 8.5. This result indicated that Posyandu counselor with poor attitude is most likely to give poor IYCF counseling practices 8.5 times greater than Posyandu counselor, which has a good attitude toward IYCF counseling practice. The practice of IYCF counseling 
will be ineffective if the counselors have problems in their ability to communicate, inappropriate knowledge, and failure to provide need-based advice were important gaps in the counseling skills of Posyandu counselors. In this study, we suggested that Posyandu counselors need to improve their practical ability to elevate their role as agents of change in public health studies.

The limitation of this study is that it does not compare the level of knowledge, attitudes, and practical skills of Posyandu counselors who have received IYCF training with counselors who have not received the training. Thus, this study has not been able to determine whether IYCF training has a significant effect on the ability of a Posyandu counselor to provide IYCF counseling.

\section{CONCLUSIONS}

Posyandu counselors' knowledge showed a low average score of 76.2. The value of the attitude of counselors from the Likert scale was 46.25 , and the practice of counselors was 68.8. Posyandu counselors with poor attitudes are most likely to give poor IYCF counseling practices 8,5 times greater than those with a good attitude. The multivariate analysis in this study indicates that the level of education, knowledge, and attitude has a significant relationship with the practice of IYCF counseling. Therefore, the level of education, knowledge, and attitude of Posyandu counselors in IYCF counseling practice is an essential factor that can support the improvement of children's nutritional status.

\section{ACKNOWLEDGMENT}

The authors are grateful for the Institute for Research and Community Services of Universitas Pendidikan Indonesia.

\section{REFERENCES}

1. Popkin BM, Corvalan C, Grummer_Strawn LM. Dynamics of the Double Burden of Malnutrition and the Changing Nutrition Reality. Lancet [Internet]. 2020;395(10217):65-74. Available from: https://pubmed.ncbi.nlm.nih.gov/31852602/

2. Suharidewi IGAT, Pinatih GI. Gambaran Status Gizi Pada Anak TK Di Wilayah Kerja UPT Kesmas Blahbatuh II Kabupaten Gianyar Tahun 2015. E-Jurnal Med [Internet]. 2017;6(6):1-6. Available from: https://ojs.unud.ac.id/index.php/eum/article/view/ 31484

3. World Health Organization. WHA Global Nutrition Targets 2025: Stunting Policy Brief [Internet]. Vol. 1, World Health Organization. Geneva: World Health Organization; 2014. 1-9 p. Available https://www.who.int/nutrition/publications/globalt argets2025_policybrief_stunting/en/

4. Partap U, Young EH, Allotey P, Sandhu MS, Reidpath DD. Characterization and correlates of stunting among Malaysian children and adolescents aged 6-19 years. Glob Heal Epidemiol Genomics. 2019;4(2):1-14.

5. Kemenkes RI. Hasil Utama Riskesdas 2018. 2018;

6. Bazzano AN, Kaji A, Felker-Kantor E, Saldanha L, Mason J. Family experiences of infant and young child feeding in lower-income countries: Protocol for a systematic review of qualitative studies. Syst Rev [Internet]. 2016;5(1). Available from: http://dx.doi.org/10.1186/s13643-016-02927

7. Budiastutik I, Nugraheni SA. Determinants of Stunting in Indonesia: A Review Article. Int J Heal Res. 2018;1(1):2620-5580.

8. Ali Z, Saaka M, Adams AG, Kamwininaang SK, Abizari AR. The effect of maternal and child factors on stunting, wasting, and underweight among preschool children in Northern Ghana. BMC Nutr. 2017;3(1):1-13.

9. Khatoon T, Mollah MAH, Choudhury AM, Islam MM, Rahman KM. Association between Infantand Child-feeding Index and Nutritional Status: Results from a Cross-sectional Study among Children Attending an Urban Hospital in Bangladesh. 2011;29(4):349-56. Available from: https://www.ncbi.nlm.nih.gov/pmc/articles/PMC3 190365/

10. Nsiah-Asamoah C, Pereko KKA, Intiful FD. Nutritional counseling interactions between health workers and caregivers of children under two years: observations at selected child welfare clinics in Ghana. BMC Health Serv Res [Internet]. 2019;19(817):1-15. Available from: https://www.ncbi.nlm.nih.gov/pmc/articles/PMC6 842228/

11. Biks GA, Tariku A, Wassie MM, Derso $\mathrm{T}$. Mother's Infant and Young Child Feeding ( IYCF ) knowledge improved timely initiation of complementary feeding of children aged $6-24$ months in the rural population of northwest Ethiopia. BMC Res Notes [Internet]. 2018;11(1):593. Available from: https://doi.org/10.1186/s13104-018-3703-0

12. Agbozo F. Qualitative assessment of counseling on infant and young child feeding provided by community health workers to caregivers at child welfare clinics in Ghana. Int J Commun Heal. 2016;(9):97-108.

13. Arzu T, Kabir Sujan A, Kumar Paul D, Ahmad T, Matin Juliana F, Hossain S. Comparative Study of Growth Monitoring \& Promotion of Children with Special Care (IYCF Counseling) and without Special Care. Am J Food Sci Technol [Internet]. 2019;7(4):104-12. Available from: http://pubs.sciepub.com/ajfst/7/4/1

14. Abebe Z, Haki GD, Baye K. Health Extension

Copyright (C) 2021; Jurnal Gizi Indonesia (The Indonesian Journal of Nutrition), Volume 10 (1), 2021

e-ISSN : 2338-3119, p-ISSN: 1858-4942 
Workers' Knowledge and Knowledge-Sharing Effectiveness of Optimal Infant and Young Child Feeding Are Associated with Mothers' Knowledge and Child Stunting in Rural Ethiopia. Food Nutr Bull. 2016;37(3):353-63.

15. Chaturvedi A, Nakkeeran N, Doshi M, Patel R. Capacity of frontline ICDS functionaries to support caregivers on infant and young child feeding ( IYCF ) practices in Gujarat, India. Asia Pac J Clin Nutr [Internet]. 2014;23(Suppl): S2937. Available from: https://pubmed.ncbi.nlm.nih.gov/25384724/

16. Kohli S, Chadha R. Knowledge and Counselling Skills of Community Health Workers for Promotion of Optimal Infant and Young Child Feeding (IYCF) Practices: A Review. Int J Heal Sci Res. 2017;7(10):240-8.

17. Manikyamba D., Vidya D.L., Satyavani A., Krishna Prasa A., Tulasi Deepthi K. Impact of Nutritional Education on the Knowledge of Mothers Regarding Infant and Young Child Feeding Practices. Sch J Appl Med Sci. 2015;3(3A):1074-8.

18. Sari M, De Pee S, Bloem MW, Sun K, ThorneLyman AL, Moench-Pfanner R, et al. Higher household expenditure on animal-source and nongrain foods lowers the risk of stunting among children 0-59 months old in Indonesia: Implications of Rising Food Prices. J Nutr. 2017;6(6):195-200.

19. Chapagain RH. Complementary feeding practices of Nepali mothers for six months to 24 months children. J Nepal Med Assoc. 2013;11(24):205-7.

20. Yenit MK, Genetu H, Tariku A. Infant feeding counseling and knowledge are the critical determinants of prelacteal feeding among HIV exposed infants attending public hospitals in Ethiopia. Arch Public Heal. 2017;75(1):1-8.

21. Zaragoza-Cortes J, Trejo-Osti LE, Ocampo-Torres M, Maldonado-Vargas L, Ortiz-Gress AA. Pobre lactancia materna, alimentación complementaria y diversidad de la dieta, y su relación con la baja talla en comunidades rurales. Nutr Hosp. 2018;35(2):271-8.

22. Faridi A, Furqan M, Setyawan A, Barokah FI. Peran Kader Posyandu dalam Melakukan Pendampingan Pemberian Makan Bayi dan Anak Usia 6-24 Bulan ( The role of cadre of maternal and child health services in the accompaniment of infant and childfeeding 6-24 Months ). 2020;5(2):172-8.

23. Perez F, Ba H, Dastagire SG, Altmann M. The role of community health workers in improving child health programs in Mali. BMC Int Health Hum Rights. 2009;9(1):1-12.

24. Articles R, Sciences H, Sciences D, Therapy O, Instructions M, New T. :: Knowledge and Couse. Hist Asp Leech Ther. 2014;3(July):1-3.

25. Kaur R, Chauhan H, Gupta N, Thakur P, Pahari S. Assessment of Accredited Social Health Activist'S
Knowledge About Health Problems and Services Being Provided By Her To People of District Ludhiana: Punjab. J Res Educ Indian Med. 2017;15(1):101-6.

26. Contento IR. Nutrition education: Linking research, theory, and practice. Asia Pac J Clin Nutr. 2008;17(1):176-9.

27. Qureshi UA, Lone KS, Mir AB. Knowledge Regarding Infant and Young Child Feeding Among Health Care Providers. 2019;6(4):92-4.

28. RI PD dan IKK. Situasi Balita Pendek (Stunting) di Indonesia [Internet]. 1st ed. Pusat data dan Informasi. Jakarta: Pusat Data dan Informasi; 2018. Available from: https://pusdatin.kemkes.go.id/folder/view/01/struc ture-publikasi-pusdatin-buletin.html

29. World Health Organization, UNICEF. Infant and young child feeding counseling: an integrated course. Who [Internet]. 2006;1-265. Available from:

http://www.who.int/nutrition/publications/IYCF_ Participants_Manual.pdf

30. Wijayanti HN, Fauziah A. Dampak Pelatihan Pmba Pada Kader Posyandu Dalam Meningkatkan Status Gizi Anak Stunting. J Gizi Dan Kesehat. 2019;11(25):1-9.

31. Wahyuningsih E, Handayani S. Pengaruh Pelatihan Pemberian Makan pada Bayi dan Anak terhadap Pengetahuan Kader di Wilayah Puskesmas Klaten Tengah Kabupaten Klaten. Motorik. 2015;10(21):55-64.

32. Patel MG, Mahyavanshi DK, Kartha G, Purani SK, Nagar SS. A cross-sectional study on knowledge, attitude, and practice regarding spacing methods among married women of the reproductive age group in the field practice area of UHTC in Surendranagar district. Heal (ISSN 2229-337X) [Internet]. 2011;2(2):2-5. Available from: http://www.iapsmgc.org/index_pdf/47.pdf 